\title{
Unsophisticated and naive? Fragmenting monolithic understandings of Islam
}

\author{
Jawad Syed $^{1 \star}$ and Edwina Pio ${ }^{2}$ \\ ${ }^{1}$ Suleman Dawood School of Business, Lahore University of Management Sciences, Lahore, Pakistan and ${ }^{2}$ Faculty of \\ Business, Economics and Law, Auckland University of Technology, Auckland, Australia \\ ${ }^{*}$ Corresponding author: Jawad.Syed@lums.edu.pk
}

\begin{abstract}
Mainstream academic literature and media use the word 'Islam' or 'Muslim' in a monolithic manner that implies internal homogeneity. However, the Islamic faith is subject to multiple interpretations, with multiple types of Muslims who practice Islam based on their ideological interpretations, sect, ethnicity and gender. Drawing on a review of literatures on Islam and Muslims from diverse fields such as religion, gender, diversity and extremism, we present a taxonomy of different types of Muslims, and highlight implications for management, organizations and governance. We trace ideological sources of divergence among variants of Islam and analyze how certain doctrinal and jurisprudential associations may reflect intolerance and extremism.
\end{abstract}

Keywords: Islam; extremism; Salafi; Shia; Sunni

\section{Introduction}

In the mainstream academic literature and media, the Islamic faith is often presented as a monolithic religion, ignoring the internal diversity or heterogeneity based on denomination, ethnicity, gender and religious practice. The monolithic understanding of Islam may be attributed to a possible lack of sophistication on the part of non-Muslim analysts as well as the general insistence of Muslim scholars that Muslims worldwide belong to one collective community, that is, the Muslim ummah. However, although there are two broad sects within Islam, that is, Sunni and Shia, the diversity within Islam is much more nuanced and heterogeneous and can be traced to different interpretations of the texts, opinions of narrators, jurisprudence and different milieus where such interpretations are enacted. For example, interpretation, geographical location and culture intersect in how gender practices such as the veil/hijab are linked to gender segregation, and injunctions on inheritance, commerce, leadership and treatment of religious and ethnic minorities, and how they are proclaimed, legislated and endorsed (e.g., Moghadam, 1994; Warde, 2000; Aitchison, Hopkins, \& Kwan, 2007; Hamid, 2016). The need for research on different understandings of Islam has been recognized for some time and a few scholars have pointed out the multiplicity of Islamic perspectives rather than 'the Islamic perspective' (Jackson, 2000; Alak, 2015). In addition, scholars signal the need to situate research on management and organizations within contextual perspectives and multiple levels of analysis (Härtel \& O'Connor, 2014).

In our guest editorial, we draw on literatures from religion, gender, diversity and terrorism, to delineate different versions of Islam and Muslims and consider implication of such diversity for organizations and societies across the globe. We conclude by outlining an agenda for future research. 


\section{Heterogeneity within islam}

In this section, we draw attention to the internal diversity of Islam, often overlooked or misunderstood in academic literature and the media. ${ }^{1}$ Nasr (2007) explains the different versions of Islam by introducing the divide between the Sunni and Shia sects of Islam as parallel to the divide between Catholic and Protestant sects in Christianity, with each claiming historic and theological orthodoxy. The origins of these two sects may be attributed to a schism that emerged after the Prophet Muhammad's death in AD 632. Shias believe that the Prophet had nominated Ali, his cousin and son-in-law as caliph after him. The Sunnis believe that the Prophet did not make any explicit nomination, therefore the new leader had to be chosen by consensus. Sunnis revere four rashidun or 'rightly guided' caliphs after the Prophet, including Ali as the fourth caliph, whereas Shias revere 12 Imams including Ali as the first Imam (spiritual leader) (Harney, 2016).

Both sects agree on many fundamental aspects of Islam, such as the oneness of God (tauhid), the Quran, the finality of the Prophet, five daily prayers, Hajj pilgrimage and yearly almsgiving (zakat) (BBC, 2009). There are, however, differences of jurisprudence on some of these matters, for example, to keep arms folded or unfolded during daily prayers. Such differences are also found within various subbranches of each of these sects.

The Shias are also distinct due to their participation in annual rituals of Ashura during the month of Muharram to commemorate the martyrdom of Imam Husayn, the Prophet's grandson, by Caliph Yazid ibn Muawiya's army in Karbala in AD 680 (Harney, 2016). Although Sunnis too revere and mourn Imam Husayn and visit his shrine in Iraq, they do not usually participate in the Shia rituals of self-flagellation.

To add nuance to the simplistic Sunni-Shia binary, Nasr states that the two largest sects are not monolithic communities and the followers of both sects are further divided into subsects based on doctrine and/or jurisprudence (such as Hanafi, Maliki, Shafii, Jafari, Ismaili and Zaidi schools of jurisprudence) and diversity of geography, language, ethnicity and class. On the basis of this premise of diversity within Islamic sects, Nasr (2007) argues that while to the Western eye, Muslim politics is defined by Islamic values, the Islamic discourse remains open to interpretation and a variety of practices. He argues that politics looks for truth in religious text but from within a perspective or context that is not purely based on religion. Individuals tend to construe, understand and read from their religious texts in line with the hopes and fears that underlie their everyday lives. Hence, it is rather unreasonable to deliberate and discuss a single Islamic reality, and even less so of one Sunni or one Shia reality.

The monolithic perspective often projected in mainstream media and academic scholarship is problematic because Muslim beliefs, interpretations and practices vary tremendously based on denomination, sect, cultural and ethnic practices, gender and religiosity. In the field of management and organization studies, this may mean that employers, managers, employees, practitioners and scholars may display naiveté in understanding the nuances within Muslim employees' belief systems and practices. A unidimensional understanding may result in organizational theories and practices based on stereotypes, sweeping generalizations and assumptions, which may be misleading and inaccurate, and misrepresent Muslims.

For example, organizations may not understand that since $9 / 11$, individuals and groups belonging to the ultraorthodox Salafi (or 'Wahhabi') and Deobandi subsects or variants of Sunni Islam are responsible for almost all incidents of suicide bombings and terrorism in the West and other parts of the world in the name of Islam (Moghadam, 2009; Syed, Pio, Kamran \& Zaidi, 2016). In addition, almost all violent Islamist organizations such as Al-Qaeda, ISIS, Taliban, Al-Shabab and Boko Haram responsible for mass murders and indiscriminate terrorism have ideological beliefs or affiliations associated with Salafism, Wahhabism or Deobandism. Victims of

\footnotetext{
'Islam' refers to the religion that was revealed to the Prophet Muhammad and subsequently enshrined into the Quran. Followers of this religion are known as 'Muslims.' The Arabic word 'Islam' has the same root as 'salaam' (peace, security and submission). The Islamic greeting 'As-salaamu alaykum' has the literal meaning 'peace be upon you.'
} 
these ultraorthodox ideologies include mainstream Sunni and Shia Muslims as well as nonMuslims across the world.

Deobandi is a puritanical subsect within Sunni (primarily Hanafi) Islam, centered in South Asia. It represents a minority of Sunni Muslims in that region. However, Deobandism is practiced by a significant number of Pashtun people in Pakistan and Afghanistan. The Deobandi diaspora is also found in the United Kingdom and South Africa. The name derives from Deoband, India, where the its first seminary Darul Uloom Deoband was founded in 1867 (Syed et al., 2016).

Salafi is an ultraconservative, literalist and censorious branch or movement within Sunni Islam that advocates a return to the traditions of the 'forefathers' (the salaf) (Wiktorowicz, 2006). In its current dominant form, Salafism developed in Arabia in the first half of the 18th century under the leadership of Muhammad ibn Abd-al-Wahhab (hence the term 'Wahhabi'). He advocated purging practices such as shrine and tomb visitation, declaring these practices to be idolatry, representative of impurities and unlawful innovation in Islam. The Salafis generally inhabit Saudi Arabia, Qatar and UAE but owing to their wealth and the growing network of madrasas and mosques are increasingly influencing ordinary Muslims across the world.

The Deobandis and the Salafis represent a tiny minority within Sunni Islam, estimated to be no more than $5 \%$ of the global Sunni population. The majority of 'ordinary' people belonging to these two branches are moderate, and reject acts of violence by the extremist factions. Arguably, in terms of their ideologies and practices, such as intolerance of other faith groups and sects within or outside Islam, these subsects are relatively more hardline and pro-Jihadist compared with mainstream Sunni, Shia or Sufi traditions of Islam. The Deobandis and the Salafis are quite similar in their rejection of what they term as bidda (impermissible innovation in religion), shirk (polytheism) and aizdira or tauheen (blasphemy), such as the Sunni and Shia rituals of Milad-un-Nabi (or Mawlid, the Prophet's birthday) and reverence of Sufi shrines.

In modern discourse, such militancy is also described as takfiri (apostatizing or exclusivist) militancy. A takfiri is an extremist Muslim who accuses other Muslim individuals, groups or entire societies of kufr (infidelity, heresy, blasphemy) due to political, ideological or sectarian differences, and resorts to violence against non-Muslims and other non-takfiri Muslims to enforce a takfiri agenda. In some instances, even moderate Salafis and Deobandis have not escaped violence at the hands of takfiri elements within their own communities (Syed et al., 2016).

In the 21st century, takfiri ideology and violence is a known characteristic of extremist sections within Salafi and Deobandi communities. Global Terrorism Index (GTI, 2014) reports that over $80 \%$ of the deaths from terrorist attacks in 2013 were in just five countries: Iraq, Afghanistan, Pakistan, Nigeria and Syria. The report suggests that from 2000 to 2013, four main groups (i.e., the ISIS, Al Qaeda, Taliban and Boko Haram with violent Salafi and Deobandi ideologies) were responsible for $66 \%$ of terror-related fatalities across the globe.

Hussain (2010) analyzed the demographic and religious characteristics of the 2,344 terrorists arrested between 1990 and 2009 in Pakistan. These terrorist cases were the ones forwarded to the courts after the police were satisfied of their guilt based on their preliminary investigation. Hussain's study shows that Deobandi militants are responsible for more than $90 \%$ of terror incidents in Pakistan.

In other words, Muslim communities have significant variances and contradictions among themselves on issues of ideology and its practice. A monolithic understanding of Islam is therefore problematic in the presence of these variants of Muslims, who not only comprehend theology, history and law differently but also breathe a distinctive ethos of faith that cultivates a specific approach and a unique temperament to the very notion of what it means to be Muslim.

The heterogeneity of the Muslim world is not hard to decipher. In 2016, Indonesian, Nigerian and Iranian Muslims protested against the Saudi government in response to the stampede that happened during the Hajj pilgrimage in 2015. These countries and their citizens and 
organizations protested over mismanagement and the high number of casualties of their pilgrims in the stampede (The Guardian, 2016). Similarly, the recent diplomatic and economic sanctions against Qatar by its fellow Arab countries, including Saudi Arabia, United Arab Emirates, Bahrain and Egypt (Wintour, 2017), are further evidence that internal diversity within the socalled Muslim world is hard to ignore.

Notwithstanding this diversity, Western discussions on Islam or on the Arab world are inclined, often implicitly, toward the Sunni interpretation (Nasr, 2007; Fisk, 2017). This inclination is not astonishing, as the vast majority of the world's Muslim population comprises Sunnis whereas Shias comprise $10-15 \%$ of the total 1.3 billion Muslims (Nasr, 2007). However, generally what is presented as a Sunni view is often that of Salafi or Deobandi clerics or organizations who represent a tiny minority within Sunni Islam. In addition, there is significant influence of Saudi- and Qatari-funded lobby groups and think tanks in the West that often present pro-Salafi views and policies as emanating from mainstream Sunni Muslims (Fisher, 2016).

Although Shia Muslims constitute a tiny minority in Southeast Asia and Africa, in the historical heart of the Islamic world, from Lebanon to Yemen, the Shia population almost compares to the Sunni population, and around the geo-strategically sensitive border of the Persian Gulf, Shias constitute almost $80 \%$ of the overall population. Again, as Nasr (2007) asserts, the Sunni version of Islam is not monolithic and consists of Salafi/Wahhabi (dominant in Saudi Arabia, UAE and Qatar), Deobandi (found mostly in South Asia), Barelvi (South Asian version of Sufis) and Sufi (worldwide) Muslims who differ on ideological and jurisprudential grounds.

However, with a monolithic interpretation of Islam, the Shia and Sunni sects tend to be represented as internally homogenous. This is not only problematic but also complicated as the takfiri (exclusivist) or extremist factions within Deobandi and Salafi/Wahhabi communities often take refuge under the Sunni umbrella, to discharge violence against other sects including mainstream Sunnis, Sufis, Shias as well as against non-Muslim communities, including Christians, Hindus, Jews and Yezidis (Moghadam, 2009; Syed et al., 2016). This deliberate appropriation of identity on the part of the takfiri factions is aimed at maintaining power and sharing identity with the majority sect, as well as at creating divides between the otherwise peaceful mainstream Sunni and Shia Muslims or between Muslims and non-Muslims.

An example of this appropriation and obfuscation of identity is the renaming of the banned Pakistani Deobandi terrorist group Sipah-i-Sahaba Pakistan to Ahle-Sunnat Wal-Jamaat (ASWJ). Sipah-i-Sahaba Pakistan was responsible for mass murders and target killing of Sunni Sufi and Shia sects and is banned in Pakistan and other countries (Tan, 2010). Its leaders, however, relaunched the group with the name Ahle-Sunnat Wal-Jamaat, thus misappropriating the formal and generic title of the Sunni sect. Mainstream Sunni (Barelvi) organizations protested this fraudulent use of their generic name by a banned terror group. However, the Ahle-Sunnat Wal-Jamaat continues to operate with the new name despite being legally banned in Pakistan (Tanoli, 2016).

Another example of misappropriation is the very name 'Islamic State' used by the violent Salafi terror group (Islamic State in Iraq and Syria aka ISIS) that has killed tens of thousands of innocent Sunni and Shia Muslims, Christians, Yezidis and other communities in the Middle East and other parts of the world. Problematically, in many sections of the Western media, the group is often described as an Islamist or Sunni militant group, thus obfuscating its true doctrinal identity and motivations under sweeping, generic and misleading titles. Indeed, ISIS's goal of establishing worldwide Islamic caliphate is in fact its agenda of enforcing its own brutal version of Salafi or Wahhabi hegemony over all people including Muslims and non-Muslims.

\section{Problems with a homogenous discourse on islam}

Historically enfolding and interpreting diverse understandings of Islamic thought under a single umbrella is problematic for several reasons. First, it reinstates the violent takfiri agenda that there 
is one mainstream Islam and any other interpretation of the Islamic discourse is heresy (Syed et al., 2016), and at the same time, denies importance to the significance of its potential implications on the global economic, social, cultural, organizational and individual levels.

Second, it is problematic in terms of identity management on the part of individuals and organizations. Adida, Laitin and Valfort (2016) observe that the Muslim community fails to integrate in Christian-majority countries due to the fear of discrimination and the contested idea of Islamophobia. They assert that it is understood and widely accepted that post-9/11, Muslims face discriminatory behaviors in their everyday lives, both in work and nonwork settings (Adida, Laitin \& Valfort, 2016). However, Erdagöz (2016) notes that despite a meticulous research design based on repeated experiments, surveys and ethnographic interviews, Adida et al. do make some overarching conclusions. For example, Erdagöz (2016) notes that the sample of Adida et al.'s study consisted of Senegalese Muslim immigrants in France, who are hardly representative of all Muslims. However, we argue that integration of liberal Muslim individuals and communities in Western societies and organizations is less of an issue or challenge than integration of hardline Salafi and Deobandi individuals or groups.

In a similar vein, Syed et al. (2016) contend that what is referred to as Islamic militancy is mostly Salafi or Deobandi militancy, whereas all Muslims might identify with the nomenclature of 'Muslim,' they vehemently condemn violence and takfiri ideology in the name of Islam. Yet, they cannot escape the discrimination on the grounds of being Muslims, often in reprisal to violent attacks by takfiri Islamist groups of Salafi and Deobandi origins. Managers concerned about religious discrimination against Muslims need to understand that the basis against which discriminatory practices have arisen cannot be associated with all Muslims alike. Thus, a prudent understanding can create a more inclusive work environment and facilitate the delineation of affirmative action in response to discrimination against Muslims, especially in situations where such affirmative action faces hostility or opposition (Qazi, 2015).

Third, different interpretations of Islamic thought have a direct impact on culture and contextual components and different groups of Muslims have distinct approaches toward life in general. For example, ultraorthodox members of Salafi and Deobandi communities have a radical and literalist approach toward the Quran and Hadith (traditions of Prophet Muhammad) and propagate puritanism (Rajashekar, 1989; Azra, 2005). In contrast, mainstream Sunni, Shia and Sufi Muslims are more open to symbolism as can be observed through the practices performed on the Prophet's birthday, that is, reciting Naats (poetry in praise of the Prophet) and playing $D a f^{2}$; or on Ashura, that is, weeping, wearing black clothes, recreating historic scenarios and so on (Nasr, 2007).

\section{Implications for management, organizations and governance}

This heterogeneity within Islam has important implications from the perspective of management, organizations and governance. Multinational corporations may need to understand that in their international operations in the Middle East and other Muslim majority regions, countries and communities, they are interacting with a range of ideologies. For example, in Saudi Arabia, Qatar and UAE, multinational corporations are likely to be dealing with Salafi and Hanbali ideology of the state, ${ }^{3}$ while in their operations in Egypt, Pakistan, Bangladesh and Turkey, it is likely to be Sunni Hanafi ideology (Knysh, 2007; Johnson \& Vriens, 2011). Similarly, in their operations in Iran, Iraq, Azerbaijan and the northern part of Yemen, they are dealing with Shia (Jafari or Zaidi)

\footnotetext{
${ }^{2} \mathrm{~A}$ large drum-like instrument.

${ }^{3}$ Although Salafis borrow their beliefs from Ibn Tamiyyah or his student Ibn Qayyim, who were followers of the Hanbali school, their doctrines are different as they do not follow a specific school of jurisprudence (mazhab or fiqh) and are more literal and puritanical.
} 
ideology, in Indonesia and Malaysia, they mainly encounter Shafii ideology, and in North Africa, they are mostly faced with Maliki ideology (Mayer, 1995; Nasr, 2007).

Though individual practices may vary, puritanical and literal interpretations and intolerance of religious and gender diversity are identifiable attributes of hardline sections within Salafi and Deobandi communities. In the West, these attributes are evident in communities affiliated or exposed to Saudi, Emirati or Qatari-funded mosques, seminaries, pamphlets and related literature. Such practices lead to ghettoization and isolation of these communities from mainstream society with strict rules of gender segregation and female seclusion (Mir \& Naquvi, 2016).

In addition, organizations may not realize important differences within Muslim communities with respect to practices of gender segregation, female seclusion, female circumcision and approaches to ethnic and religious diversity. This is evident in relatively less restrictions on women's mobility and employment in Hanafi-dominated Turkey and Pakistan as compared with Salafi- or Wahhabi-dominated Saudi Arabia. In Pakistan, the presence of women at Sufi shrines and festivals is in stark contrast to strict norms of gender segregation and female seclusion in practicing Deobandi and Salafi communities. Similarly, the presence of sizable Jewish population in Shia-dominated Iran is in stark contrast to elimination of entire Jewish population from the Salafi/Wahhabi-dominated Saudi Arabia and many other countries in the Middle East (Sengupta, 2016).

When Muslims travel from their source countries to immigrate and/or work in Western countries or typically in non-Muslim majority countries, they carry with them their traditions and ways of being, not only into the receiving countries' societies but also into the organizations situated in these countries. Add to this, the influx of refugees into Europe, many of whom are Muslims, from countries such as Syria, Afghanistan, Iraq and Somalia and the complexity of the management and diversity of the workforce within an organization increases exponentially.

Although such diversity can be viewed as an ominous challenge, it is also a multifarious opportunity to share the richness of the threads that unite humanity and for organizations to serve as leaders, nurturers, path-breakers and path-creators in forging sophisticated talent management and growth opportunities. Indeed, if we hark back to the period when Islam was known for its scientific advancements and humane treatment of all societies, we note that the Ottoman Empire welcomed Jews when they were persecuted in many parts of Europe (Fatah, 2011). Furthermore, during the Irish potato famine in the 19th century, the Ottoman Caliph Abdul Mejid wanted to contribute 10,000 pounds but was requested by Queen Victoria not to contribute this amount, as that would overshadow her contribution of 2,000 pounds (Hayes, 2016). In the Indian subcontinent, we have the example of the 16th century Mughal Emperor Akbar who institutionalized and implemented a pluralist policy of the sulh-e-kul (absolute peace) for people of diverse faiths and sects (Syed, 2011).

In terms of denominational diversity, there are varied approaches to community leadership. For example, in Sunni Islam, the first four caliphs (the rashidun) are most prominent after the Prophet Muhammad, and after them importance is accorded to the four Imams of jurisprudence (Abu Hanifa, Malik, Shafii and Ahmed ibn Hanbal) (Makdisi, 1979). In contrast, in Shia Islam, Prophet Muhammad and his 12 descendants (12 Imams) are considered the legitimate spiritual leaders (Abdal-Haqq, 2002). In the modern era, the institution of taqleed or followership (in religious matters) of a competent cleric is an integral part of the Twelver Shia ideology (Akhavi, 1988). In contrast, in Sunni Islam, there is no such central authority and as such different clerics, organizations and countries use their own influence to direct and indoctrinate Sunni Muslims (Ruthven, 2012). In the absence of central control, there is thus a possibility within organizations and wider society that some Muslim and non-Muslim individuals may be influenced by radical ideologies of extremist groups.

There are also financial implications of such differences. For example, in Sunni Islam, zakat (2.5\% religious tax on total savings and wealth) may be given to any needy person or community based on the donor's discretion, whereas in Shia Islam an additional khums tax (20\% of all gains 
and profits) is mandatory, which must be distributed through a competent cleric (Mallat, 1988; Karim, 2014).

There are further distinctions within Islam. For example, Sufi Muslims (within Sunni and Shia sects) pay special attention to the construction and maintenance of shrines and there are legal trusts or awqaf registered for management of these buildings and funds, and contribute to public welfare (Green, 2004). In contrast, in ultraorthodox Salafi and Deobandi traditions, shrines are not permissible and must be leveled to the ground. Some members of these ultraorthodox traditions seem to endorse violence and attacks on Islamic shrines (often maintained and managed by Sunni, Sufi and Shia Muslims) (Fair, 2011). Frequently, many mainstream Sunni, Shia and Sufi practices and religio-cultural rituals are described as bidda (unlawful religious innovation) and shirk (polytheism) by Salafi and Deobandi clerics and extremist groups.

On a global scale, radical Salafi and Deobandi groups may indulge in practices of intolerance and discrimination directed against women and/or religious and ethnic minority groups within or outside Islam (Fair, 2011; Syed et al., 2016). This may result in particular gender discriminatory and exclusionary practices and laws, for example, restrictions in Saudi Arabia on women's driving and independent mobility. In contrast, some interpretations of Islam are relatively more pluralistic, such as the presence of people of diverse faiths, ethnicities and gender at Sufi shrines and Ashura (Muharram) rituals (Iraqi News, 2009). In addition, though in somewhat diverse ways, both mainstream Sunni and Shia Muslims practice the rituals of Sufi shrines and Ashura.

In terms of diversity, while there is evidence of commitment to equality - based on gender, ethnicity and race - within several injunctions of the Quran and the Hadith (traditions of Prophet Muhammad), actual practices vary greatly across societies, cultures and organizations (Syed \& Pio, 2017). Thus, the status and roles of women in the Salafi/Wahhabi-dominated Saudi Arabia are different to those in Shafii-dominated Malaysia or Hanafi-dominated Turkey and Pakistan (Kandiyoti, 1991). With respect to diversity within Islam, it is important to consider intersectionality of gender with Islamic denomination and ethnicity because these additional layers may greatly shape equal opportunities or lack thereof facing Muslim women (Pio, 2010; Syed \& Van Buren, 2014). Such additional layers may also reflect potential exposure and vulnerability of Muslim women to intolerant and extremist ideologies.

Similarly, the treatment of ethnic minority and migrant workers remains a sore point in the UAE, Qatar and other Gulf countries (Gibson, 2016). Moreover, there seems to be greater commitment to cultural heritage, arts and music in Central and South Asia than in countries dominated by Salafi ideology (Batsh, 2016). There are also disparities because of urban/rural background and regions. These may exist within a single country. For example, in the case of Iran, women in Tehran, the capital city, seem to be relatively more independent and active in everyday life and employment when compared with women in more rural locations such as Qom and Zahedan (Farsian, 2003).

The literalism-symbolism divide is important for organizational contexts because these attitudes have the tendency to be translated into work behaviors (e.g., Ghazal Read, 2004). There is, thus, a need for identification of Muslims not by a monolithic perspective but a more fine-grained understanding of their doctrinal affiliations and practices. The majority of ordinary Muslims may not be able to (or may prefer not to) explain these nuances and internal diversities within Sunni, Shia and other denominations of Islam. Yet, their attitudes toward women and people of diverse faiths and sects within and outside Islam and their approach toward the goal of a worldwide caliphate and elimination of bidda and shirk may reveal their levels of tolerance and integration (or lack thereof). In organizational settings, this would help in developing an informed understanding of different types of Muslims, in ensuring general security within and outside the workplace, and also in creating discrimination-free working environment for the dominant majority of tolerant and peaceful Muslims. Such an approach 


\begin{abstract}
Question \#: 9850
Mufti Sahab, Assalamualikum, Please guide whether greeting christian people on 25/Dec --MERRY CHRISTMAS is correct or not??? also tell about other religion festivals like diwali etc.....if it's is not jayaz,then what is the best way of wishing non muslim on their respective festival? Since non muslim

friends/neighbour/collegue greets us on our festivals like eid etc,ls it not our courtesy to greet them also on their festival. Please guide in the light of shariah. 2 . Also advise wishing someone (muslim \& non muslim both) HAPPY NEW YEAR on Ist Jan is also correct or not?????
\end{abstract}

$$
\text { بم الش الرحن الرجما }
$$

(Fatwa: 50/48=B/1429)

Wishing ?merry Christmas? to Christians on 25 December is not right. Likewise, congratulating people of other religions on their festivals is not correct. Yes, one can express his wishes in good words like praying for peace and tranquillity or for security of the country or mutual unity and integrity.

It is also not proved to wish someone with Happy New Year on 1 January.

Allah knows Best!

Darul Ifta,

Darul Uloom Deoband

Figure 1. Deobandi fatwa against 'Merry Christmas'

would also help identify takfiri and potentially violent Muslims who may cause harm to fellow employees. For example, in a shooting incident in St. Bernardino, a 'Muslim' couple, Farook and Tashfeen, shot 14 people at Inland Regional Center, a social services agency. Allegedly, one of the 14 victims had an argument with the killer concerning Islam, which agitated the killer into carrying out a morbid act violence (Cabrera, Carroll \& Dart, 2015). The killers are known to have connections with radical Deobandi and Salafi/Wahhabi ideology (Syed, 2015). Other news sources claim that the killer was forced to pose for a photograph at a mandatory Christmas dinner, which according to the Federal Bureau Investigation was his potential motive for the shooting (Massarella, 2016). The news article shows the bearded killer Farook posing for the photograph with his arms uncomfortably at his sides. Farook's purported aversion to Christmas celebrations is an example of his intolerance for symbolism and cultural diversity, which is a characteristic of Salafi and Deobandi Muslims who refer to Christmas celebrations as haram (Taylor, 2009).

A leading Deobandi cleric Taqi Usmani wrote a detailed article describing the participation of Muslims in Christmas and other similar festivals as forbidden in Islam (Usmani, 2015). In 2009, the Darul Uloom Deoband, the oldest and most credible Deobandi seminary in the world, issued a fatwa (religious ruling on issues pertaining to Islamic law, usually in response to questions by ordinary Muslims) declaring that Muslims were not allowed to wish 'Merry Christmas' to Christians. The fatwa also forbade Muslims from congratulating people of other religions on their festivals or to wish someone on New Year. Figure 1 offers a screen image of the fatwa (Darul Ifta Deoband, 2009).

Such exclusivist fatwas are likely to create isolationist and intolerant attitudes within their circle of influence. In extreme cases, they enable a takfiri mindset. Disagreement and alternate understandings of theology and conduct are despised by takfiris who display intolerant and misogynistic behaviors pertaining to anything other than their version of religion. In another incident, a 'Muslim' named Omar Mateen shot 49 people at a gay club in Orlando (Spargo, 2016). According to his co-workers, Omar was a rage-filled homophobe who uttered nasty words at the sight of women and people of color.

In yet another incident of faith-based violence in the workplace, Nidal Hasan, a US Army major and psychiatrist, fatally shot 13 people and injured more than 30 others in a mass shooting 
at Fort Hood, TX, USA in November 2009. According to the news reports, he was indoctrinated by Anwar al-Awlaki, an Al-Qaeda-affiliated cleric (Memri, 2009).

In all of the above examples, the news from mainstream media did not mention doctrinal or jurisprudential affiliations of the killers, while mentioning them as Muslims. Having established the notion that 'Muslim' is not a monolithic title, such journalism and research can be described as misleading and problematic for both organizations and mainstream Muslim employees.

\section{Overview of papers}

The papers included in this special issue of 'Journal of Management and Organization' are the first attempt in scholarly literature to focus on internal heterogeneity of Islam and outline its implications for management and organizations. An overview of the papers selected for this issue is provided in this section.

In their paper titled, 'The diversity of professional Canadian Muslim women: Faith, agency, and "performing" identity,' Latif, Cukier, Gagnon and Chraibi examine how identities are constructed and performed by Muslim women in the Canadian workplace. Their study provides fresh insights on how these women disclose or 'perform' their identities in different contexts. Drawing on interviews with 23 professional Muslim women in Canada, the study builds on and adds to the literature on identity construction of ethnic minorities, intersectionality and the workplace experiences of Muslim women. The authors discuss important implications for understanding Muslim women's identity work in broader contexts of discrimination as well as accommodation and inclusion in organizations.

Next paper in this special issue is titled, 'Contextualizing comprehensive board diversity and firm financial performance: Integrating market, management and shareholder's perspective.' In this paper, Hassan and Marimuthu examine demographic, cognitive diversity and internal diversity within Islam at the top level of management and its impact on financial performance of Malaysian-listed companies. The study also examines Muslim and nonMuslim women and religious diversity on corporate boards. Data from 330 Malaysian-listed companies in 11 full-fledged sectors were used for the period from 2009 to 2013. The study used econometrics methodology from panel data analysis to fill the research gap in the current management literature. The study used the interaction approach to examine empirically diverse corporate boards and their impacts on firm performance. This discussion included: (1) a combination of gender diversity and ethnic diversity and (2) the combination of gender diversity with foreign participation. The findings suggest that demographic, cognitive and internal diversity within Islam are significant predictors of a firm's financial performance. Ethnic women on boards have a significant and negative impact on firm performance. Hence, companies having high profits are more accountable for encouraging diversity among toplevel management.

In their paper titled, "Good Muslim women" at work: An Islamic and postcolonial perspective on ethnic privilege,' Ali and Syed argue that within sparse studies available on ethnic privilege at work, the emphasis is dominantly on ethnic privileges available to white, AngloSaxon, Protestant, heterosexual men and, to a lesser extent, white women. Their paper presents and develops an Islamic and postcolonial perspective on ethnic privilege, which is unique not only due to contextual and cultural differences but also due to its postcolonial nature and composition. By postcolonial, the authors refer to cultural legacies of Arab colonialism and ideology in South Asia and elsewhere. Drawing on a study of Muslim female employees in Pakistan, the authors show that religio-ethnic privilege represents postcolonial influences of a foreign (Arab-Salafi, ultraorthodox Islamist) culture on a non-Arab Muslim society, and as such does not represent ethnic norms of a local mainstream society. The paper investigates the case of religio-ethnic privilege and female employment in Pakistan and examines how a foreigninfluenced stereotype used to benchmark "good Muslim women." 
Finally, in their paper titled, 'Entrepreneurship as worship: A Malay Muslim perspective,' Sidek, Pavlovich and Gibb focus on variations in the interpretations of Islamic law (i.e., Sharia). The authors argue that this variation may hold the key in explaining the different behaviors among Muslim entrepreneurs because of their views on the concept of work as worship. In their study, they examine how Malay entrepreneurs are guided in their sourcing and shaping of entrepreneurial opportunities through the Shaffi school of jurisprudence. The authors identify five central values that guide the participants' sourcing of opportunities: Fardhu Kifayah (communal obligation), Wasatiyyah (balanced), Dakwah (the call of joining the good and forbidding the bad), Amanah (trust) and Barakah (blessings). Their study contributes to the entrepreneurship literature by demonstrating how these macro-level values of worship give the entrepreneurs confidence in creating their new ventures.

\section{Agenda for future research and concluding comments}

In this special issue, we have sought to introduce the concept of heterogeneity within Islam to organizational and management studies literature. However, much research still awaits this domain. Future researchers may conduct detailed empirical investigations of Muslims of various types and the implications of such diversity for organizations and societies. There is also need for ethnographic studies that investigate the psychological patterns and work habits that underlie intolerance inside and outside workplaces.

Associating acts of intolerance and violence to all Muslims has had negative impact on many peaceful Muslims (TRT World, 2016). Post 9/11, incidents of violence and discrimination against Muslims have resulted with the ascendance of Islamophobia, and its implications are faced by all Muslims regardless of their sect or involvement in any intolerant or violent activity. Individuals have multiple identities and in order to incriminate a culprit, it is important to pinpoint the precise ideology that instigated the particular crime. Muslim is a large identity shared by various, different groups of people; it is thus important to identify the variant of Islam or Muslim that tends to preach or promote intolerance or violence.

Our call for further scholarship on this topic delves into the ideological and cultural contexts, as well as the past, present and future as a lens, for a more erudite and refined understanding and interpretation of Islamic heterogeneity in the context of management and organizations. This call is especially important given the lack of studies that engage with the diversity and complexity in various kinds of organizations, diverse theoretical frameworks, methodologies and ensuing management practices, which highlight the heterogeneity within Islam. There is, therefore, a need to take a contextual perspective, whether it be positioning Islam, culture and history or management and organizations as context (Härtel \& O'Connor, 2014).

Through this editorial and special issue, we have provided a glimpse of the ideological and cultural heterogeneity of Islamic thought and alluded to its implications for management and organizations. We have also put out a clarion call for further research to investigate various types of Islam and Muslims and their inherent differences and potential organizational implications of these differences. Given the dearth of research on context in organizational behavior (Jones, 2006), scholarship that contextualizes Islam and Muslims is vital for a more refined and less clumsy understanding of this important aspect of religious diversity in organizations and societies.

Through a nuanced understanding of heterogeneity within Islam, we can engage with the dominant majority of peaceful Muslims in mutually productive and inclusive ways within and outside the workplace. Moreover, extremist ideologies and radicalized subsects that represent only a tiny minority of Muslims and pose challenges to security, diversity and peaceful coexistence can be more astutely understood. In academic scholarship and media projections, it is important to clearly identify and separate such extremist ideologies and communities from the 
majority of peaceful Sunni and Shia Muslims. As a final word, it is instructive to remember that Islam means peace.

\section{References}

Abdal-Haqq, I. (2002). Islamic law-an overview of its origin and elements. Journal of Islamic Law \& Culture, 7, 27.

Adida, C. L., Laitin, D. D. \& Valfort, M. A. (2016). Why Muslim integration fails in Christian-heritage societies. Cambridge: Harvard University Press.

Aitchison, C., Hopkins, P. \& Kwan, M. (2007). Geographies of Muslim identities: Diaspora, gender and belonging. Hampshire: Ashgate.

Akhavi, S. (1988). Islam, politics and society in the thought of Ayatullah Khomeini, Ayatullah Taliqani and Ali Shariati. Middle Eastern Studies, 24(4), 404-431.

Alak, A. I. (2015). Types of religious identities within Romanian Muslim communities. Journal for the Study of Religions and Ideologies, 14(41), 148-173.

Azra, A. (2005). Islam in Southeast Asia: Tolerance and radicalism. Melbounre: Centre for the Study of Contemporary Islam, Faculty of Law, University of Melbourne.

Batsh, M. E. (2016). Arab Israeli Salafists take aim at sports and culture. The Times of Israel, June 2. Retrieved from: http:// www.timesofisrael.com/arab-israeli-salafists-take-aim-at-sports-and-culture/

BBC (2009). Sunni and Shi'a. BBC, August 19. Retrieved from: http://www.bbc.co.uk/religion/religions/islam/subdivisions/ sunnishia_1.shtml

Cabrera, Y., Carroll, R. \& Dart, T. (2015). San Bernardino shooting victim 'had argued with killer about Islam'. The Guardian, December 5. Retrieved from: https://www.theguardian.com/us-news/2015/dec/05/san-bernardino-victim-hadargued-with-shooter-about-islam

Darul Ifta Deoband (2009). Darul Ifta of Darul Uloom Deoband. Question 9850. Retrieved from: http://www.daruliftadeoband.com/home/en/Halal-Haram/9850

Erdagöz, H. (2016). Why Muslim integration fails in Christian-heritage societies. Ethnic and Racial Studies, 39(13), 2437-2439.

Fair, C. C. (2011). The militant challenge in Pakistan. Asia Policy, 11(1), 105-137.

Farsian, B. (2003). Iran's holiest city launches its first all-female taxi service. The Telegraph, October 11. Retrieved from: http://www.telegraph.co.uk/news/worldnews/middleeast/iran/1443896/Irans-holiest-city-launches-its-first-all-femaletaxi-service.html

Fatah, T. (2011). The Jew is not my enemy: Unveiling the myths that fuel Muslim anti-semitism. Oxford: Signal Books.

Fisher, M. (2016). How Saudi Arabia captured Washington. Vox, March 21. Retrieved from: https://www.vox.com/2016/3/ 21/11275354/saudi-arabia-gulf-washington

Fisk, R. (2017). Donald Trump's speech to the Muslim world was filled with hypocrisy and condescension. The Independent, May 21. Retrieved from: http://www.independent.co.uk/voices/donald-trump-saudi-arabia-muslim -speech-a7747856.html

Ghazal Read, J. N. (2004). Family, religion, and work among Arab American women. Journal of Marriage and Family, 66(4), 1042-1050.

Gibson, O. (2016). Migrant workers suffer 'appalling treatment' in Qatar World Cup stadiums, says Amnesty. The Guardian, March 31. Retrieved from: https:/www.theguardian.com/global-development $/ 2016 / \mathrm{mar} / 31 /$ migrant-workers-sufferappalling-treatment-in-qatar-world-cup-stadiums-says-amnesty

Green, N. (2004). Emerging approaches to the Sufi traditions of South Asia: Between texts, territories and the transcendent. South Asia Research, 24(2), 123-148.

GTI (2014). Global Terrorism Index - Vision of Humanity. Retrieved from: visionofhumanity.org/app/uploads/2017/04/ Global-Terrorism-Index-Report-2014.pdf

Hamid, S. (2016). Sufis, Salafis and Islamists: The contested ground of British Islamic activism. London: IB Tauris.

Harney, J. (2016). How do Sunni and Shia Islam differ? The New York Times, January 3. Retrieved from: https://www. nytimes.com/2016/01/04/world/middleeast/q-and-a-how-do-sunni-and-shia-islam-differ.html

Härtel, C. E. J. \& O'Connor, J. M. (2014). Contextualizing research: Putting context back into organizational behavior research. Journal of Management \& Organization, 20(4), 417-422.

Hayes, C. (2016). Little known tale of generous Turkish aid to the Irish during the Great Hunger. Irish Central. Retrieved from: http://www.irishcentral.com/roots/history/little-known-tale-of-generous-turkish-aid-to-the-irish-during-the-greathunger

Hussain, S. E (2010). Terrorism in Pakistan: Incident patterns, terrorists' characteristics, and the impact of terrorist arrests on terrorism (PhD Thesis, Penn Dissertations Paper 136). http://repository.upenn.edu/edissertations/136

Iraqi News (2009). Ninewa delegation in Karbala to meet religious clerics. March 17. Retrieved from: http://www.iraqinews. com/baghdad-politics/ninewa-delegation-in-karbala-to-meet-religious-clerics/ 
Jackson, S. A. (2000). Islam and affirmative action. Journal of Law and Religion, 14(02), 405-431.

Johns, G. (2006). The essential impact of context on organizational behavior. Academy of management review, 31(2), 386-408.

Johnson, T. \& Vriens, L. (2011). Islam: Governing under Sharia. New York: Council on Foreign Relations.

Kandiyoti, D. (1991). Women, Islam, and the state. Philadelphia: Temple University Press.

Karim, K. H. (2014). Aga Khan development network: Shia Ismaili Islam. In S. M. Cherry, \& e Ebaugh H. R. (Eds), Global Religious Movements Across Borders: Sacred Service (pp. 143-160). Surrey: Ashgate.

Knysh, A. (2007). Contextualizing the Salafi-Sufi conflict (from the Northern Caucasus to Hadramawt). Middle Eastern Studies, 43(4), 503-530.

Makdisi, G. (1979). The significance of the Sunni schools of law in Islamic religious history. International Journal of Middle East Studies, 10(1), 1-8.

Mallat, C. (1988). Religious militancy in contemporary Iraq: Muhammad Baqer as-Sadr and the Sunni-Shia paradigm. Third World Quarterly, 10(2), 699-729.

Massarella, L. (2016). San Bernardino killer was livid over mandatory Christmas lunch. New York Post, December 1. Retrieved from: http://nypost.com/2016/12/01/san-bernardino-killer-was-livid-over-mandatory-christmas-party/

Mayer, A. E. (1995). Reform of personal status laws in North Africa: A problem of Islamic or Mediterranean laws? The Middle East Journal, 49(3), 432-446.

Memri (2009). Maj. Nidal Hasan, Fort Hood shooter and lone-wolf jihadi, celebrated and lionized by terror groups and leaders. Memri, August 15. Retrieved from: https://www.memri.org/reports/maj-nidal-hasan-fort-hood-shooter-and-lonewolf-jihadi-celebrated-and-lionized-terror-groups

Mir, R. \& Naquvi, M. A. (2016). Fighting the Takfiris: Building an inclusive American Muslim community by countering Anti-Shia rhetoric in the USA. In J. Syed, E. Pio, T. Kamran, \& A. Zaidi (Eds), Faith-Based Violence and Deobandi Militancy in Pakistan (pp. 399-421). Basingstoke: Palgrave Macmillan.

Moghadam, A. (2009). Motives for martyrdom: Al-Qaida, Salafi Jihad, and the spread of suicide attacks. International Security, 33(3), 46-78.

Moghadam, V. M. (1994). Gender and national identity: Women and politics in Muslim societies. London: Palgrave Macmillan.

Nasr, V. (2007). The Shia revival: How conflicts within Islam will shape the future. New York: WW Norton \& Company.

Pio, E. (2010). Islamic sisters: Spirituality and ethnic entrepreneurship in Sweden. Equality, Diversity \& Inclusion, 29(1), 113130.

Qazi, M. (2015). Affirmative action - A new agenda for Indian Muslims. Chicago Monitor, October 19. Retrieved from http://chicagomonitor.com/2015/10/affirmative-action-a-new-agenda-for-indian-muslims/

Rajashekar, J. P. (1989). Islamic fundamentalism. The Ecumenical Review, 41(1), 64-72.

Ruthven, M. (2012). Islam: A very short introduction. Oxford: OUP.

Sengupta, K. (2016). Iran's Jews on life inside Israel's 'enemy state': 'We feel secure and happy'. The Independent, March 16. Retrieved from: http://www.independent.co.uk/news/world/middle-east/irans-jews-on-life-inside-israels-enemy-state-wefeel-secure-and-happy-a6934931.html

Spargo, C. (2016). 'He always talked of killing people': Former co-worker of Orlando terrorist says he warned his security firm bosses. Daily Mail, June 13. Retrieved from: http://www.dailymail.co.uk/news/article-3638935/He-talked-killingpeople-Former-worker-Orlando-terrorist-says-deranged-homophobic-toxic-racist-hated-women-loved-violence.html

Syed, J. (2011). Akbar's multiculturalism: Lessons for diversity management in the 21 st century. Canadian Journal of Administrative Sciences, 28(4), 402-412.

Syed, J. (2015). From Karachi to San Bernardino: In quest of an alternative discourse on terrorism. The Huffington Post, December 8. Retrieved from: http://www.huffingtonpost.co.uk/jawad-syed/san-bernardino-karachi-terrorism_b_8740002. html

Syed, J. \& Pio, E. (2017). Muslim diaspora in the West and international HRM. The International Journal of Human Resource Management, 28(8), 1109-1118.

Syed, J., Pio, E., Kamran, T. \& Zaidi, A. (2016). Faith-based violence and Deobandi militancy in Pakistan. Basingstoke: Palgrave Macmillan.

Syed, J. \& Van Buren, H. J. (2014). Global business norms and Islamic views of women's employment. Business Ethics Quarterly, 24(2), 251-276.

Tan, A. T (Ed.) 2010). Politics of Terrorism: A Survey. Abingdon: Routledge.

Tanoli, Q. (2016). Banned groups continue to resurface under new names. The Express Tribune, June 8. Retrieved from: https://ribune.com.pk/story/1118483/weak-enforcement-banned-groups-continue-resurface-new-names/

Taylor, J. (2009). Can a Muslim say happy Christmas to his friends? The Independent, November 26. Retrieved from: http://www.independent.co.uk/news/uk/this-britain/can-a-muslim-say-happy-christmas-to-his-friends- 1827628. html

The Guardian (2016). Iranians protest against Saudi Arabia before hajj pilgrimage. September 9. Retrieved from: https:// www.theguardian.com/world/2016/sep/09/iranians-protest-saudi-arabia-hajj-pilgrimage 
TRT World (2016). Discrimination against Muslims spikes in France, England. Retrieved from: http://www.trtworld.com/ europe/discrimination-against-muslims-spikes-in-france-england-151299

Usmani, T. (2015). Rabi'ul-Awwal. Albalagh. Retrieved from: https:/www.albalagh.net/general/rabi-ul-awwal.shtml

Warde, I. (2000). Islamic finance in the global economy. Edinburgh: Edinburgh University Press.

Wiktorowicz, Q. (2006). Anatomy of the Salafi movement. Studies in Conflict \& Terrorism, 29(3), 207-239.

Wintour, P. (2017). Qatar facing further sanctions as ultimatum deadline looms. The Guardian, July 2. Retrieved from: https://www.theguardian.com/world/2017/jul/02/qatar-facing-further-sanctions-as-ultimatum-deadline-looms

Cite this article: Syed J, Pio E. 2018. Unsophisticated and naive? Fragmenting monolithic understandings of Islam. Journal of Management \& Organization 24: 599-611. doi: 10.1017/jmo.2018.55 